\title{
International Practice of Environmental Challenges Regulation
}

\author{
Galina Chistyakova ${ }^{1, *}$, Anastasia Rolgayzer $^{1}$, Evgeniya Bondareva $^{2}$, and Inessa Schlee ${ }^{1}$ \\ ${ }^{1}$ Plekhanov Russian University of Economics, Kemerovo Institute (branch), 650992, 39 Kuznetskiy \\ Av., Kemerovo, Russia \\ ${ }^{2}$ Beijing Language and Culture University, 100083, 15 Xueyuan Road, Beijing, China
}

\begin{abstract}
Modern society needs to establish a balance between social and economic development and environment conservation. This target can be met through the integrated use of legislative, economic and administrative measures developed and implemented by various international, national and regional organizations. Environmental management can achieve the maximum efficiency only through the joint use of three environmental policy instruments: direct regulating, market-based instruments, and voluntary programs. Direct regulating is inherently directive in terms of establishing emission standards / discharge limits, industry product and process specifications, and transparency reporting requirements. The implementation of market-based instruments depends on the day-to-day use of private sector financial calculations. Economic methods include price-based instruments and property-based instruments. Voluntary programs, actively encouraged by governments, offer intangible rewards such as public recognition. The vast legislative framework and activities of governmental and public organizations encourage mining and processing enterprises to strictly conform to environmental rules and regulations. While multiple market-based instruments of environmental management and voluntary programs provides businesses with greater autonomy in choosing ways, means and terms of restructuring their environmental policies to meet pressing environmental challenges.
\end{abstract}

\section{Introduction}

In recent years, environmental issues and the rational use of natural resources have become a great challenge both for individual countries and on a global scale. Establishing the optimum balance between environmental problems and accelerating scientific and technical progress presupposes developing eco-analytical methodology [1], on the one hand, and selecting the right operating methods and technologies of environmental management, on the other hand.

A number of organizations dealing with regulation of environmental activities have already been established and are working effectively. The United Nations Organization has undoubtedly come to the fore. The organization itself and all its main bodies and

\footnotetext{
*Corresponding author: galvik06@mail.ru
} 
specialized agencies monitor ecological activities of nation states, develop recommendations and statutory acts for the countries of the world community that are aimed at improving the social and ecological situation in the world.

There are also international non-governmental organizations, whose activities are mainly related to the solution of issues that are not affected by the activities of governments, but require public attention. They encourage governments to conclude relevant agreements and form public opinion. The major well-known non-governmental organizations include: Greenpeace, the International Union for Conservation of Nature, the International Socio-Ecological Union, the International Association "Green Cross", etc.

The vast legislative framework and activities of governmental and public organizations encourage mining and processing enterprises around the world not only to conform to the environmental laws, regulations, and standards, but also actively restructure their policies to meet pressing environmental challenges. In countries with developed market economies, in addition to administrative and legal regulation mechanisms, command-and-control and market-based instruments are effectively applied.

\section{Materials and methods}

The key link between economic, social and environmental challenges in the modern world is the concept of sustainable development of society, designed to establish a balance between the solution of social and economic problems and environmental conservation. The implementation of this concept requires developing a system of legislative, economic and administrative measures aimed at protecting the environment, regulating pollutants emissions by industrial enterprises, as well as developing mechanisms to promote and encourage careful nature users.

The UN Conference on Environment and Development, held in Rio de Janeiro, Brazil, in 1992 (also known as the Earth Summit), has become a turning point in addressing issues of environment protection. Its Agenda 21 proclaimed the desire of most countries to move to a model of sustainable development, according to which the needs of people should be met with the maximum preservation of the environment.

At the 2015 UN Climate Change Conference (COP 21, 2015), an important agreement was reached to strengthen the global response to the threat of climate change in the context of sustainable development and poverty eradication efforts. Besides, a number of challenges requiring a special attention were identified:

1. Not all countries are ready to immediately start reducing greenhouse gas emissions. For example, the Chinese government predicts an increase in emissions up to 2030 and only later is ready to reduce them.

2. A number of developing countries require an individual approach. The leaders of developing countries claim that they need to use fossil fuels, such as coal, gas, oil, in order to overcome poverty. Thus, the Paris agreement had to strike a balance between the need to reduce greenhouse gas emissions and the right to use fossil fuels.

3. Some experts note that the absence of a common centralized system for monitoring the Agreement compliance will lead to non-implementation of the arrangements reached.

4. There is a lack of clear criteria for identifying developed and developing countries that would help to determine which countries should provide financial assistance, and which countries need it themselves.

5. There are some financial issues challenges. Developing countries consider that the Agreement does not set out the obligations of so-called "rich countries" to finance climate change projects. 
6. There are still disagreements on the necessity to impose strict legal restrictions.

In order to prevent and/or minimize environmental damage, a number of direct and indirect environment policy instruments have been developed and applied in different countries [2-3]. At the same time, it is believed that the maximum efficiency in overcoming current and future ecological threats can be achieved only through the joint use of three instruments of environmental policy: direct regulation, market-based instruments, and voluntary programs.

Direct regulation is inherently directive in terms of establishing emission standards / discharge limits, industry product and process specifications, and transparency reporting requirements. In fact, regulators use command-and-control measures, when there is not enough information to apply a market-based regulatory instrument, or if the activity is carried out in a weak market where any profit will be neutralized by costs [4-6].

However, the inflexibility of standards and requirements is both an advantage and a disadvantage of this ecological and economic instrument. It is obvious that direct regulation can and does have a positive effect. For example, according to the US Environmental Protection Agency, emissions of lead and industrial nitrogen have decreased significantly in the US since the 1970s, the renovated sewage effluents quality has improved, and energy consumption by high-energy and other manufacturing firms has decreased. At the same time, as noted by manufacturers, direct regulation, especially technological specifications that establish emission standards, as well as the cost of meeting these requirements, leave no room for innovation and do not stimulate compliance with these standards.

Because of the obvious drawbacks of direct regulation of environmental activities the market-based instruments have taken the leading positions in the global environmental practice. A distinctive feature of market-based instruments for environmental regulation is that their implementation depends on the daily use of private sector financial calculations. Unlike direct regulation, where the agent is required direct-acting, market decisions are made by enterprises independently.

Market-based economic instruments are generally considered to fall into two categories: price-based instruments and property-based instruments. The two categories function differently. In the first case, bilateral interaction of the taxpayer, on the one hand, and the government, on the other, is assumed. In the second case, several parties may participate in the process. For example, in the case of permit trading, an organization may sell a pollution permit issued to it by the government. Then the transactions continue until the valid permits are returned to the government at the end of the year in accordance with the permissible levels of pollutant emissions. Both categories can function in parallel, as, for example, it occurs in the United States with respect to the same ozone-depleting chemicals.

In many countries, voluntary programs have become a new important trend in environmental management. In contrast to market-based instruments, voluntary programs offer intangible remuneration such as public recognition and access to information on ways of reducing pollution at no costs or their minimum level. Governments encourage voluntary initiatives for a variety of reasons, including pilot testing of new approaches and lack of legislative authority to create mandatory programs. Thus, many voluntary programs offer unique approaches to environmental management.

\section{Results and discussion}

The basis for practical activities in the field of the European Union environmental policy are medium-term programs, which are political and legal documents that identify priority activities for the near future and set out specific goals and objectives. For example, the EU 
environmental policy is regulated by the 7th Environment Action Programme (the 7th EAP) that is valid for the period up to 2020. The program defines three main objectives: to protect, preserve and strengthen the EU natural capital; to make the EU economy a resource-efficient, environmentally friendly and competitive low-carbon economy; and to protect the EU citizens from threats and risks to their health and well-being associated with the adverse environment.

In Europe, with a high concentration of economic activity, pollution spreads beyond the borders of a single country. For example, $90 \%$ of the acid rain in the Nordic countries is of foreign origin. Poland receives about $40 \%$ of all pollution from abroad, Hungary - up to 35 $\%$, the Czech Republic and Slovakia - 40-45\%, in Austria more than $80 \%$ of the sulfur oxide falling on its territory is brought from other countries.

The EU countries increasingly apply indirect methods of environmental management that include: charges on the use of natural resources (mineral, water, land, forest), pollutant emissions taxes, tax relieves, etc. This group of methods provides firms with greater autonomy in choosing ways, means and terms of improving their environmental policy than methods of direct regulation. In the 1990s, the EU countries implemented "greening" of tax systems aimed at promoting resource saving and reducing environmental pollution.

The environmental policy of the CIS countries is regulated by the Interstate Council on Ecology, established in 1992. It coordinates the interaction of the CIS member states in addressing issues of environmental safety and giving impetus to environmental cooperation. Within the framework of this Council, various agreements are adopted, for example, on cooperation in the field of environmental monitoring; on information cooperation in the field of ecology and environmental protection, etc. The main tasks and functions of the Council are: coordinating the environment protection policy of the CIS member states through the development of recommendations; preparing recommendations for the harmonization of regulatory legal acts in the field of environmental protection, etc.

The existence, at the national level, of effective mechanisms to promote environmental management and protection in most countries of Western Europe, Japan, the United States is the result of many years of research. Despite the fact that these states have achieved significant scientific and technological achievements, they keep on causing huge environmental damage to nature. However, foreign developed countries have accumulated vast experience in the development of environmental legislation and its implementation.

The main principles of environmental and economic regulation in the US are the prevention of environmental consequences, their neutralization and compensation for damage. In general, currently in the US, almost all natural resources and facilities are subject to regulation by the state. The US Federal legislation in the field of environmental protection is divided into two groups. The first group includes the National Environmental Policy Act (NEPA), which imposes on Federal agencies the duty to protect the environment and defines some methods and technologies used for environmental policy implementation such as environmental standards, a preliminary assessment of the impact on the environment, long-term programming of environmental activities, etc. It is supplemented with the Environmental Quality Improvement Act. An important role in these legislative acts is assigned to the environmental impact assessment, which is an assessment of the environmental impact of industrial development projects. The main objective is to predict the probable danger of the proposed economic activity at the planning stage and to assess the rationality of measures in terms of the reasonable use of natural resources and environmental protection. The second group of legislation includes: the Clean Air Act, the Clean Water Act, the Resource Conservation and Recovery Act, the Toxic Substance Control Act, etc. 
Environmental tax instruments are one of the most effective environmental instruments used worldwide. For the first time the need for their use was identified in the Environment Action Programmes of the European Union in 1973, that stated the principle "polluter pays". This principle assumes that the introduction of environmental taxes should stimulate environmental and resource-saving activities.

Types of taxes vary depending on the type and size of the business. Businesses can get tax relieves or environmental taxes expenditures, if they use a lot of energy due to the peculiarities of their activities, acquire energy-efficient technologies, or they are small businesses without significant energy input.

Environmental taxes are nationally specific. For example, in the UK, the main financial instruments of environmental policy regulating environmental activities of businesses include: Climate Change Levy, Emissions Trading, CRC Energy Efficiency Scheme, Landfill Tax, and others.

The Climate Change Levy was introduced in 2001 to realize the UK commitments for greenhouse gas reduction. Tax rates are set up per unit of amount of electricity or mass unit of the energy source material (coal, natural gas, liquefied petroleum gas). The tax is paid at basic rates charged for energy supplied to the ultimate user or at CPS rates for industrial energy users.

Due to the fact that the aim of the tax introduction was to increase energy efficiency, the UK government has created a number of mechanisms to help taxpayers to achieve this goal. In particular, the Carbon Trust, an independent non-profit organization funded by the government, was established. This organization offers practical recommendations for improving energy efficiency, as well as stimulates research, development and implementation of advanced technologies in the field of renewable energy sources and technologies that minimize air emissions. The country also has various investment funds targeted at financing energy efficiency projects, for example, the UK Energy Efficiency Investments Fund, run by SDCL's investment business.

Emissions Trading concerns energy-intensive enterprises and involves the purchase and sale of permits for greenhouse gas emissions in order to reduce the negative impact on the environment by the organization. If an organization joins the EU Emissions Trading System, it should strive to achieve its goals by reducing its own emissions and participating in emissions trading. Large enterprises not falling under the Emissions Trading System are subject to the CRC Energy Efficiency Scheme.

The CRC Energy Efficiency Scheme applies to large energy consumers in the public and private sectors in the UK, including supermarkets, water supply companies, banks, local authorities and all central government departments. All organizations that meet the qualifying requirements must participate in this scheme without fail. They must buy permits for every ton of greenhouse gas emissions.

The Landfill Tax was introduced in 1996 in order to reduce waste production and promote its recycling as well as encourage cleaner ways to recycle waste. The tax is imposed on waste dumped in official landfills. The Landfill Tax is not paid in the case of dredging, mining, pet cemeteries and inert waste used to fill open-pits, or if the waste is recycled, incinerated or reused.

In the EU, taxes on non-returnable beverage containers, plastic bags, power supplies, chemical fertilizers are widely used. For example, in Italy there is a tax on plastic bags; in the Netherlands and Sweden - on the use of sulphate fertilizers; in France - on beverage packaging.

The EU countries are also characterized by the use of environmental insurance of economic activities which are aimed at insuring the risk of environmental pollution. Business entities pay insurance fees depending on the degree of their environmental hazard. 
Accumulated in special insurance funds, such payments form the basis for guaranteed compensation of damages caused to the environment and recipients.

Germany, Denmark, the Netherlands and a number of other countries widely use pollution permit trading as a market-based instrument of environmental regulation. Enterprises have different levels of marginal costs to reduce environmental pollution. Comparing the size of theses marginal costs with the market price of pollution permits, they make independent decision on the feasibility of buying (or selling) such permits and their quantity. If the marginal costs exceed the market price of permits, it is more profitable to buy some additional pollution permits, rather than reduce emissions, and vice versa.

In recent years, environment certificates (or green certificates), as a modified form of environmental licenses, has gained widespread use in a number of countries (France, Sweden, the Netherlands and Great Britain). These certificates are an environmental policy instrument that combines methods of direct administrative regulation with the advantages of the market-based instruments.

The use of environmental taxation instruments is formed at different levels of government. Different types of environmental payments / charges may vary not only between different countries, but also within the same state at the regional level.

For example, Air Emission Permit Fees are regulated at the state level of the United States. Amendments to the Clean Air Act suggest that each state charges a fee for permission to cover the administrative costs of programs approved by the United States Environmental Protection Agency. The amendments set the minimum presumptive level for such charges per ton of toxic emissions. Each state is required to establish a fee that fully covers the emission permit program. If the fees are below the statutory minimum, state authorities provide detailed evidence that these fees are sufficient to cover the costs of the program.

Effluent Fees in different US states are based on different principles. For example, in California, the annual fees of the National Pollutant Discharge Elimination System (NPDES) varies depending on the level of potential threat to water quality (categories I, II, III, where I is the maximum level) and the complexity of issuing permits (categories a, b, c, where $\mathrm{a}$ is the maximum complexity). Thus, I-a rating permit holders pay a maximum fee. The collected funds go to financing the State Water Board programs.

Product charges are also widespread all over the world. In the United States, this type of payment is divided into two parts: charges set at the national level (Federal Product Charges) and charges set at the level of individual states (State Product Charges). Examples of the first group include fuel charge, transportation charge, transportation equipment charge and chemicals charges. At the state level, environmentally harmful products such as beverage containers, fertilizers, furniture, motor oil, pesticides, refrigerators, solvents and tires are subject to taxation.

Subsidies targeted at reducing environmental pollution can take various forms: grants, low interest credits, a favorable tax regime and preferential procurement policy for products that are expected to cause relatively low environmental risks. Subsidies are used to support pollution prevention and control in the private sector, to clean up polluted industrial facilities, to manage consumer waste, etc. Despite many criticisms, subsidies have become a fairly common instrument for environmental management at all levels of government.

Voluntary Programs have become an important new trend in environmental management all over the world. This trend is associated with the introduction of waste reduction methods as well as the methods of preservation and improvement of resource efficiency. They increase the added value of the business, its competitiveness and reduce environmental pollution. Unlike market-based regulatory instruments that provide financial incentives for organizations and individuals to expand environmental protection activities, 
voluntary programs offer non-financial reward, such as public recognition and access to information on ways to reduce pollution at no costs or their minimum level.

Most voluntary environmental programs in the US have been developed and implemented by the United States Environmental Protection Agency, but there are also programs developed by industrial and trade organizations. Unlike government programs which are primarily aimed at reducing pollution, industry initiatives are developed to improve public opinion. Another reason for corporate participation in voluntary programs is that the sponsoring regulatory body can provide technical support to participants. Such assistance may be considered as a subsidy. In addition, voluntary programs sometimes make it possible to limit potentially high legal, regulatory and executive expenses.

\section{Conclusion}

In modern conditions, the impact of the environmental factor on the sustainable social and economic development becomes very significant. The balance between social and economic development and environmental conservation can be established through the implementation of the system of legislative, economic and administrative measures developed by individual states (regions) and the international community.

Environmental management can meet its main targets only through the joint use of three environmental policy instruments: direct regulating, market-based instruments, and voluntary programs. While implementing direct regulating techniques, regulators use command-and-control measures that are inherently directive in terms of industry product and process specifications, establishing emission standards / discharge limits, as well as transparency reporting requirements. Due to vast legislative framework, activities of governmental and public organisations as well as multiple market-based instruments of environmental management the world community will be able to meet pressing environmental challenges.

\section{References}

1. M. I. Agienko, E. P. Bondareva, G. V. Chistyakova, O.V. Zhironkina, O. I. Kalinina, IOP Conf. Series: Earth and Environmental Science, 50, 012022 (2017)

2. R. Rybár, M. Beer, M. Cehlár, Measurement, 88, 153-164 (2016)

3. I.A. Kudryashova, E.A. Kharlampenkov, N.V. Zakharova, Izvestiya Ferrous Metallurgy, 61:11, 914-919 (2018) DOI: 10.17073/0368-0797-2018-11-914-919

4. I. Kudryashova, E. Kharlampenkov, N. Zakharova, A. Kolevatova, E3S Web Conf., 41, 02025 (2018)

5. M.A. Gasanov, K.A. Kolotov, K.A. Demidenko, E.A. Podgornaya, O.V. Kadnikova, IOP Conf. Ser.: Earth Environ. Sci., 50:1, 012025 (2017)

6. M. Cehlár, J. Janočko, Z. Šimková, T. Pavlik, M. Tyulenev, S. Zhironkin, M. Gasanov, Resources, 8:1, 21 (2019) 